\title{
HUBUNGAN IKLIM DENGAN KEJADIAN PENYAKIT LEPTOSPIROSIS DI INDONESIA: LITERATUR REVIEW
}

\author{
Muhammad Mirza Ramadhan'1, Sri Devi1, Tirana Cahya Mahrani Ismail1, \\ Zaitun Mulyani', Ramadhan Tosepu ${ }^{1^{*}}$ \\ ${ }^{1}$ Jurusan Kesehatan Lingkungan Fakultas Kesehatan Masyarakat, \\ Universitas Halu Oleo, Jl.H.E.A Mokodompit Kecamatan Anduonohu, Kota Kendari \\ E-mail: ramadhan.tosepu@uho.ac.id
}

\begin{abstract}
Corelation Between Climate And Leptospiros Disease In Indonesia: Literature Review Leptospirosis is a direct zoonosis where transmission occurs directly, without the use of other vectors, and humans are accidental hosts that are unintentionally related to infective animals or Leptospira contaminated material. Leptospirosis is a public health problem throughout the world, especially tropical and subtropical countries that have high rainfall, and is also a major problem in temperate regions. Leptospirosis is zoonosis due to Leptospira bacteria. Leptospirosis is a whole world with a broad spectrum of animals as its host. Infection that occurs in humans that occurs, after contact with air or other materials contaminated with animal waste. The aim is to study the relationship with the incidence of leptospirosis. The method used in this article is a literature review. Library sources used in preparation of literature review use journal articles from 2015 to 2017, the process of searching through Google Scholar articles. Journal discussion results show air temperature, humidity, increase in rainfall, air $p H$, and flood events have an influence on leptospirosis. Relationship between events with leptospirosis. The conclusion in this journal explains that there is a relationship between complications and the incidence of leptospirosis.
\end{abstract}

Keywords: Leptospirosis; climate; rainfall; temperature; water pH; humidity; flood.

\begin{abstract}
Abstrak: Hubungan Iklim Dengan Kejadian Penyakit Leptospirosis Di Indonesia: Literatur Review. Leptospirosis merupakan direct zoonosis dimana penularannya terjadi secara langsung, tanpa memerlukan vektor lain, dan manusia merupakan accidental hospes yang secara tidak sengaja kontak dengan hewan infektif atau material yang terkontaminasi Leptospira. Leptospirosis merupakan masalah kesehatan masyarakat di seluruh dunia, khususnya negaranegara yang beriklim tropis dan subtropis yang memiliki curah hujan tinggi, dan juga merupakan masalah besar pada wilayah yang beriklim sedang. Leptospirosis merupakan zoonosis akibat bakteri Leptospira .Leptospirosis terdapat di seluruh dunia dengan spectrum hewan yang luas sebagai hospesnya. Infeksi yang terjadi pada manusia terjadi secara kebetulan, setelah kontak dengan air atau bahan lain yang tercemar kotoran hospes hewan. Tujuan untuk mengetahui hubungan iklim dengan kejadian penyakit leptospirosis. Metode yang digunakan dalam penulisan artikel ini adalah literature review. Sumber pustaka yang di gunakan dalam penyusunan literature review menggunakan artikel jurnal dari tahun 20152017, proses pencarian artikel melalui Google Scholar. Hasil penulisan Jurnal menunjukan suhu udara, kelembaban udara, tingginya curah hujan, $p H$ air, dan kejadian banjir memiliki pengaruh terhadap penyakit leptospirosis. Sehingga menunjukkan bahwa secara tidak langsung ada hubungan antara iklim dengan kejadian penyakit leptospirosis. Kesimpulan dalam penulisan jurnal ini adalah menjelaskan ada hubungan antara iklim dengan kejadian penyakit leptospirosis.
\end{abstract}

Kata Kunci: Leptospirosis; iklim; Curah hujan; Suhu; pH air; Kelembaban; Banjir.

\section{PENDAHULUAN}

Leptospirosis merupakan direct zoonosis dimana penularannya terjadi secara langsung, tanpa memerlukan vektor lain, dan manusia merupakan accidental hospes yang secara tidak sengaja kontak dengan hewan infektif atau material yang terkontaminasi Leptospira (Setiawan IM, 2008). 
Leptospirosis merupakan masalah kesehatan masyarakat di seluruh dunia, khususnya negaranegara yang beriklim tropis dan subtropis yang memiliki curah hujan tinggi, dan juga merupakan masalah besar pada wilayah yang beriklim sedang (WHO, 2003). Leptospirosis merupakan zoonosis akibat bakteri Leptospira . Leptospirosis terdapat di seluruh dunia dengan spectrum hewan yang luas sebagai hospesnya. Infeksi yang terjadi pada manusia terjadi secara kebetulan, setelah kontak dengan air atau bahan lain yang tercemar kotoran hospes hewan (Rusmini, 2011).

Sejarah modern leptospirosis dimulai pada tahun 1886 ketika Adolph Weil menjelaskan suatu jenis tertentu dari penyakit kuning disertai dengan splenomegali, disfungsi ginjal, konjungtivitis, dan ruam kulit. Penyakit tersebut kemudian diberi nama penyakit Weil (Adler B, 2015). Demam Weil atau biasa disebut dengan leptospirosis adalah infeksi akut yang disebabkan oleh bakteri leptospira. Leptospirosis ditularkan melalui kontak dengan air, tanah, dan lumpur yang tercemar bakteri leptospira; kontak dengan organ, darah dan urine hewan yang terinfeksi; serta mengkonsumsi makanan yang terkontaminasi (Widiyono, 2008).

Leptospirosis merupakan masalah kesehatan masyarakat di seluruh dunia, khususnya Negara-negara yang beriklim tropis dan subtropis yang memiliki curah hujan tinggi. Kejadian leptospirosis untuk negara subtropis adalah berkisar antara 0,11 kejadian tiap 100.000 penduduk per tahun, sedangkan di negara tropis berkisar antara 10-100 kejadian tiap 100.000 penduduk per tahun (WHO, 2003). Leptospirosis adalah salah satu penyakit infeksi yang terabaikan atau Neglected Infectious Diseases (NIDs) yaitu penyakit infeksi yang endemis pada masyarakat. Leptospirosis adalah penyakit infeksi akut yang dapat menyerang manusia maupun hewan (zoonosis). Penyakit ini disebabkan oleh Leptospira interrogans, kuman aerob (termasuk golongan Spirochaeta) yang berbentuk spiral dan bergerak aktif. Penyakit ini pertama kali dilaporkan oleh Adolf Weil pada tahun 1886. Penyakit tersebut ada miskin atau populasi petani dan pekerja yang berhubungan dengan air dan tanah di negar berkembang. Leptospirosis merupakan zoonosis yang paling luas tersebar di seluruh dunia, kecuali daerah kutub (Rusmini, 2011).

Penularan leptospirosis berkaitan dengan faktor lingkungan, baik lingkungan abiotik maupun biotik. Faktor lingkungan abiotik meliputi indeks curah hujan, suhu udara, suhu air, kelembaban udara, intensitas cahaya, $\mathrm{pH}$ air, dan $\mathrm{pH}$ tanah. Faktor lingkungan biotik meliputi vegetasi, keberhasilan penangkapan tikus (trap success), dan prevalensi Leptospira pada tikus (Rusmini, 2011).

Leptospirosis di Indonesia pada tahun 2012 sebanyak 239 penderita yang meninggal 29 orang (CFR 12,13\%), tahun 2013 mengalami peningkatan kasus Leptospirosis sebanyak 640 penderita yang meninggal 60 orang (CFR 9,38\%). Kasus Leptospirosis pada tahun 2014 sedikit mangalami penurunan sebanyak 519,penderita yang meninggal 61 orang (CFR 11,75\%) (Kementrian Kesehatan Indonesia, 2015).

Dinas Kesehatan Provinsi Jawa Tengah melaporkan pada adanya peningkatan jumlah kasus leptospirosis. Pada tahun 2016 jumlah kasus leptospirosis sebesar 4,82 per 100.000 penduduk, namun pada tahun 2017, hingga bulan September, telah dilaporkan terjadi kasus sebesar 9,92 per 100.000 penduduk dengan CFR 16,17\% (Dinas Kesehatan Provinsi Jawa Tengah, 2017).

Kabupaten Boyolali merupakan daerah endemis Leptospirosis. Pada tahun 2016 jumlah kasus Leptospirosis di Kabupaten Boyolali sebesar 6,25 per 100.000 penduduk, namun pada tahun 2017, hingga bulan Agustus, telah dilaporkan jumlah kasus Leptospirosis mencapai 40,62 per 100.000 penduduk dengan CFR sebesar $23,52 \%$.

\section{BAHAN DAN CARA PENELITIAN}

Metode yang digunakan dalam penulisan ini adalah literature review. Sumber pustaka yang di gunakan dalam penyusunan literature review menggunakan artikel jurnal dari tahun 2015- 2019 proses pencarian artikel melalui Google Scholar. Artikel jurnal yang di temukan menggunakan bahasa Indonesia dan keywords yang di gunakan dalam pencarian 
jurnal adalah hubungan iklim dengan kejadian penyakit leptospirosis . Artikel jurnal yang ditemukan berjumlah 19 jurnal, kemudian kami konversikan menjadi 7 jurnal dan dari jurnal tersebut hanya 4 jurnal yang membahas secara spesifik mengenai hubungan iklim dengan penyakit leptospirosis.

\section{HASIL PENELITIAN DAN PEMBAHASAN}

\begin{tabular}{|c|c|c|c|}
\hline Judul & Penulis & Tahun & Metode \\
\hline Analisis Faktor & Arief Nugroho & 2015 & Rancangan penelitian \\
\hline Lingkungan & & & yaitu cross \\
\hline dalam Kejadian & & & dilakukan \\
\hline Leptospirosis di & & & observasi \\
\hline Kabupaten & & & pengukuran lingkungan \\
\hline Tulungagung & & & $\begin{array}{lr}\text { abiotik dan } & \text { observasi } \\
\text { kondisi } & \text { rumah } \\
\text { penduduk. } & \end{array}$ \\
\hline
\end{tabular}

\begin{tabular}{llll}
\hline Analisis Pola & Lirih Setyorini, 2017 & Desain penelitian ini \\
Persebaran & Nurjazuli dan & adalah cross sectional \\
Penyakit & Hanan Lanang & dengan menggunakan \\
Leptospirosisdi & Dangiran & jenis penelitian studi \\
Kota Semarang & & observasional secara \\
Tahun 2014 - & & deskriptif & serta \\
2016 & & menggunakan analisis \\
& & spasial.
\end{tabular}

\begin{abstract}
Hasil
Suhu udara rata-rata sebesar $27,27^{\circ} \mathrm{C}$ sangat mendekati rentang optimal pertumbuhan Leptospira sp. Bakteri leptospira sp. yang tumbuh pada kondisi yang lembab sangat sesuai dengan kondisi lingkungan di lokasi penelitian yaitu sebesar $77.67 \%$. Faktor nilai pH air di lokasi penelitian juga mendukung dalam pertumbuhan bakteri leptospira sp. Yaitu sebesar 7,00 . Hal ini didukung pula dengan kondisi salinitas, klorin, dan kadar oksigen terlarut air yang sesuai dengan pertumbuhan bakteri leptospira sp.
\end{abstract}

Kasus leptospirosis banyak terdapat di daerah dengan curah hujan menengah 101 - $300 \mathrm{~mm} /$ bulan yaitu sebanyak 76 kasus (56,7\%). Meskipun di daerah yang memiliki curah hujan $<100 \mathrm{~mm} /$ bulan dan $>300 \mathrm{~mm} /$ bulan juga terdapat kasus namun jumlahnya tidak sebanyak di daerah dengan curah hujan menengah. Penelitian Annisa Rahim yang dilakukan pada tahun 2013 menggambarkan bahwa kejadian Leptospirosis banyak terjadi pada Kecamatan dengan curah hujan diatas $177,6 \mathrm{~mm}$.

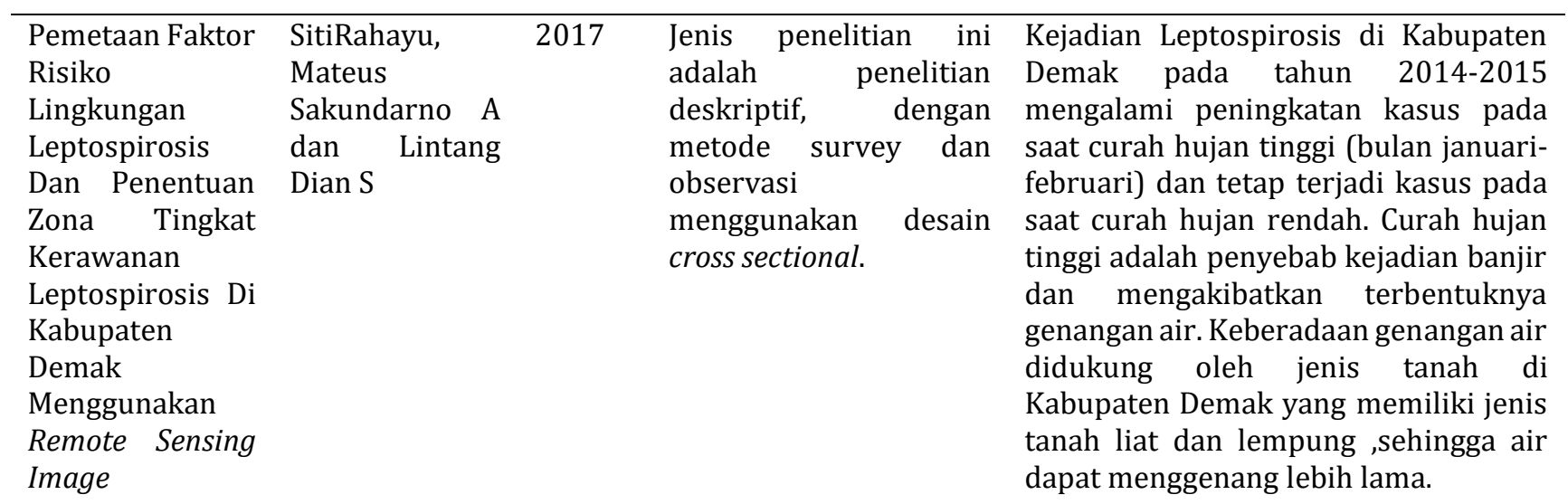

$\begin{array}{llll}\text { Judul } & \text { Penulis } & \text { Tahun } & \text { Metode }\end{array}$




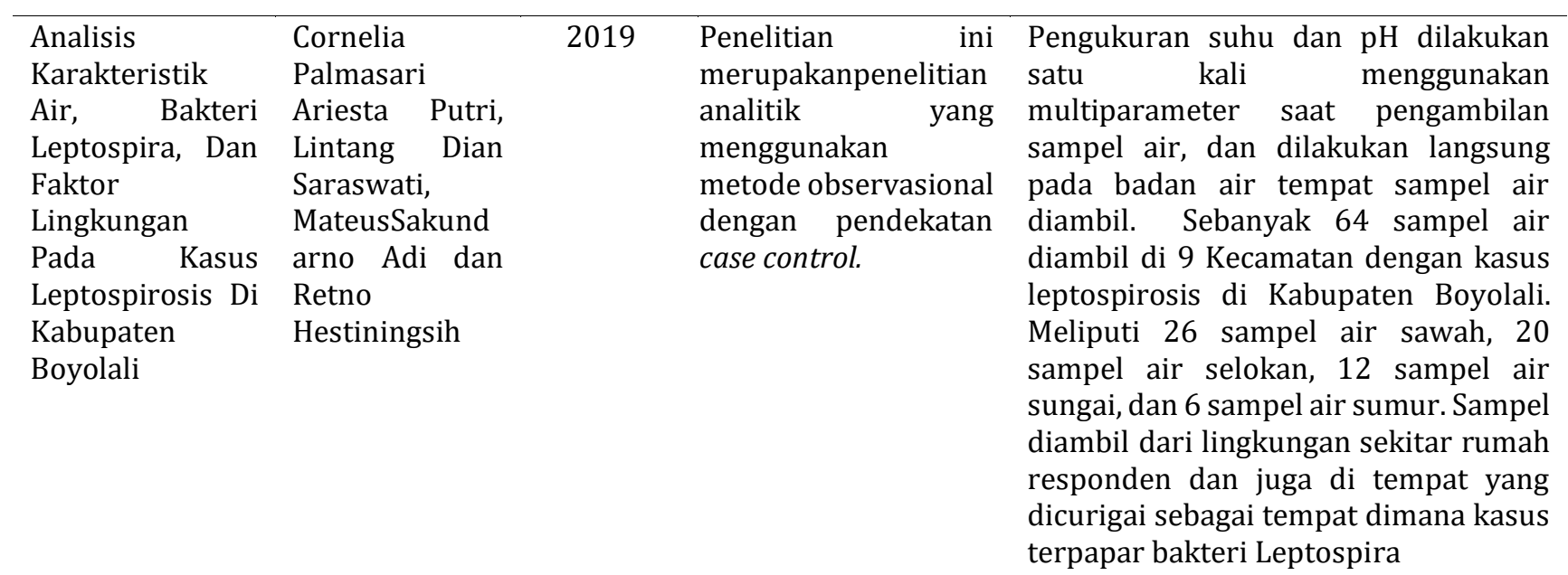

Penelitian yang dilakukan oleh Arief Nugroho, 2012 dengan judul Analisis Faktor Lingkungan dalam Kejadian Leptospirosis di Kabupaten Tulungagung. Menjelaskan bahwa pada pengukuran lingkungan abiotik luar dan dalam rumah didapatkan rata-rata suhu udara dan kelembaban udara berturutturut $\quad 27,90^{\circ} \mathrm{C} \quad$ dan76,55\%. Bakteri Leptospira sp. dapat bertahan di air pada suhu berkisar $28-30^{\circ} \mathrm{C}$ (Tunissea A, 2008). Sedangkan kelembaban udara optimal untuk perkembangbiakan bakteri Leptospira sp. Pada suasana basah/lembab lebih dari 31,4\% (Sumanta H, dkk , 2015) dan (Yunianto B., 2010). Berdasarkan hal tersebut, suhu udara rata-rata dirumah penduduk mendekati suhu optimal dan kelembaban udara rata-rata sangat mendukung pertumbuhan bakteri Leptospira sp. di luar inangnya, sehingga proses penularan dengan perantara air maupun tanah sangat besar. Pada pengukuran $\mathrm{pH}$ air di bak mandi didapat rata-rata sebesar 7,65. Kondisi $\mathrm{pH}$ air tersebut sangat menunjang pertumbuhan bakteri Leptospira sp. (pH optimal 6,2-8). Manusia dapat terinfeksi melalui kontak dengan air di bak mandi jika telah dikotori oleh urin tikus yang lewat di atas kamar mandi jika tidak tertutup oleh plafon (Tunissea A, 2008).

Penelitian yang dilakukan oleh Lirih Setyorini, Nurjazuli dan Hanan Lanang Dangiran 2017, jurnal tentang Analisis Pola Persebaran Penyakit Leptospirosisdi Kota
Semarang Tahun 2014 - 2016 . Menunjukkan bahwa terdapat tiga mekanisme yang dapat digunakan untuk menjelaskan hubungan antara curah hujan dan kejadian leptospirosis. Mekanisme yang pertama adalah meningkatnya curah hujan merupakan kondisi yang optimal bagi tikus untuk bereproduksi sehingga terjadi peningkatan populasi tikus, yang berarti meningkatnya juga kemungkinan terjadinya leptospirosis. (Davis S, 2005). Mekanisme yang kedua adalah tingginya curah hujan mengakibatkan terjadinya banjir yang membuat banyak tikus keluar dari persembunyiannya dan masuk ke lingkungan perumahan, hal tersebut meningkatkan risiko terjadinya penularan leptospirosis. (Tassinari., 2008) Mekanisme yang ketiga adalah adanya perbedaan curah hujan meningkatkan risiko manusia untuk terpapar permukaan air yang telah terkontaminasi bakteri leptospira. (Dassanayake DL, Wimalaratna H 2009). Air hujan yang kemungkinan sudah terkontaminasi bakteri leptospira melalui urine tikus mengalir melalui sungai dan meluap sehingga membentuk genangangenangan di jalan raya.

Penelitian yang dilakukan oleh SitiRahayu, Mateus Sakundarno A dan Lintang Dian S, 2017. Jurnal tentang Pemetaan Faktor Risiko Lingkungan Leptospirosis Dan Penentuan Zona Tingkat Kerawanan Leptospirosis Di Kabupaten Demak Menggunakan Remote Sensing Image. 
Menunjukkan bahwa Ketinggian tempat dari permukaan laut merupakan variable penting terhadap sebaran kasus Leptospirosis, kondisi ketinggian tempat sangat terkait dengan area/lokasi luasan banjir dan terbentuknya genangan-genangan air permanen (Sunaryo, 2010). sebagian besar (98,9\%) wilayah Kabupaten Demak merupakan dataran rendah, kecuali sebagian wilayah yang di Kecamatan Mranggen dan Kecamatan Karangawen merupakan wilayah yang memiliki ketinggian $=47-100 \mathrm{mdpl}$. Kondisi wilayah Kabupaten Demak yang sebagian besar merupakan wilayah dataran rendah maka lebih dari separuh wilayahnya dimanfaatkan sebagai persawahan irigasi. Keberadaan sungai besar atau sungai irigasi yang menyebar menjadi faktor yang kuat untuk terjadi banjir jika musim hujan tiba. Banjir terjadi diakibatkan oleh luapan air sungai. Kebiasaan warga membuang sampah disungai membuat volume sungai mengecil dan meluapkan airnya jika debit air mulai tinggi. Selain itu, hasil penilitian juga menunjukkan bahwa responden tinggal pada perumahan yang kondisi saluran pembuangan airnya buruk dan sarana tempat pembuangan sampahnya juga buruk. Jika diamati sepintas tidak ada hubungan antara kejadian Leptospirosis dan banjir. Untuk melihat faktor risiko air banjir dilaksanakan dengan menganalisis pernah tidaknya responden kontak dengan air banjir. Hasil penelitian menunjukkan probabilitas kontak dengan air banjir akan mengalami sakit Leptospirosis 23 kali dibandingkan penduduk yang tidak kontak dengan air banjir (Supraptono B, 2011).

Hasil penelitian yang dilakukan oleh Cornelia Palmasari Ariesta Putri, Lintang Dian Saraswati, Mateus Sakundarno Adi dan Retno Hestiningsih, 2019. Dengan judul jurnal Analisis Karakteristik Air, Bakteri Leptospira, Dan Faktor Lingkungan Pada Kasus Leptospirosis Di Kabupaten Boyolali. Menunjukkan bahwa karakteristik sampel air yang diambil pada penelitian ini, dimana sebagian besar sampel air memiliki suhu dan pH yang tidak optimal. Namun dari semua sampel air, tidak ditemukan adanya bakteri Leptospira dengan pemeriksaan molekuler menggunakan PCR. Hal ini dipengaruhi oleh jangka waktu pengambilan sampel air dengan kejadian leptospirosis yang cukup lama, sehingga memungkinkan terjadinya perubahan lingkungan atau hilangnya bakteri Leptospira di lingkungan. Selain itu penentuan titik pengambilan sampel air juga mempengaruhi peluang ditemukannya bakteri Leptospira pada sampel air. Hal tersebut patut dijadikan kewaspadaan terhadap penularan mendatang karena kemungkinan keberadaan bakteri Leptospira di air dan lingkungan masih sangat besar, ditambah dengan keberadaan tikus yang merupakan hospes utama Leptospirosis di lingkungan, semakin memperbesar peluang terjadinya penularan Leptospirosis pada manusia baik secara langsung maupun tidak langsung.

\section{KESIMPULAN DAN SARAN}

Dari beberapa jurnal yang ditemukan dapat disimpulkan bahwa suhu udara ratarata di rumah penduduk mendekati suhu optimal dan kelembaban udara rata-rata sangat mendukung pertumbuhan bakteri Leptospira sp. di luar inangnya, sehingga proses penularan dengan perantara air maupun tanah sangat besar., pengaruh tingginya curah hujan merupakan kondisi yang optimal bagi tikus untuk bereproduksi sehingga terjadi peningkatan populasi tikus, yang berarti meningkatnya juga kemungkinan terjadinya leptospirosis. probabilitas kontak dengan air banjir akan mengalami sakit Leptospirosis. karakteristik sampel air yang diambil pada penelitian ini, dimana sebagian besar sampel air memiliki suhu dan $\mathrm{pH}$ yang tidak optimal. Sehingga dari keempat jurnal tersebut memiliki hubungan antara iklim dengan kejadian penyakit leptospirosis.

Diharapkan dengan adanya jurnal ini dapat memberikan manfaat bagi semua orang dan dapat membantu menyelesaikan persoalan mengenai materi yang telah dibahas. Sehingga dengan adanya penulisan ini dapat mengetahui hubungan iklim dengan kejadian penyakit leptospirosis di Indonesia. 


\section{KEPUSTAKAAN}

1. Adler B, E. (2015). Leptospira and Leptospirosis. Australia: Springer Berlin Heidelberg.

2. Dassanayake DL, H. W. (2009). Evaluation of surveillance case definition in the diagnosis of leptospirosis, using the Microscopic Agglutination Test: a validation study. BMC Infect Dis. 2009. 9(48).

3. Davis S, dkk. (2005). Fluctuating rodent populations and risk to humans from rodentborne zoonoses. Vector Borne Zoonotic Dis. 2005. 5(4), 3015-3314.

4. Dinas Kesehatan Provinsi Jawa Tengah. (2017). Buku Saku Kesehatan Tri Wulan 3 Tahun 2017. Semarang: Dinas Kesehatan Provinsi Jawa Tengah.

5. Kementerian Kesehatan, I. (2015). Rencana strategis Kementrian Kesehatan Tahun 2015-2019. Jakarta: Kementrian Kesehatan RI.

6. Rusmini. (2011). Bahaya Leptospirosis (Penyakit kencing tikus) \& Cara Pencegahannya. 2, 3, 4, 14, 15, 59-85.

7. Setiawan IM. (2008). Pemeriksaan Laboratorium untuk Mendiagnosis Leptospirosis. Media Litbang Kesehatan. 2008. XVIII(1), 44-52.

8. Sumanta H. (2015). Spatial analysis of Leptospira sp. in rats, water and soil in Bantul District Yogyakarta Indonesia. Open Journal of Epidemiology, 5, 22-31.

9. Sunaryo. (2010). Mapping and Determination of Leptospirosis vulnuerable zone Based on Geographical Information System in Semarang City. 2010. 2, 1-10.

10. Supraptono B. (2011). Interaksi 13 Faktor Risiko Leptospirosis. 2011. 27(2), 55-65.

11. Tassinari., P. (2008). Detection and modelling of case clusters for urban leptospirosis. Trop Med Int Heal. 2008. 13(4), 503-512.

12. Tunissea A. (2008). Faktor lingkungan abiotik pada kejadian leptospirosis. BALABA. 2008;7(2):23.

13. WHO. (2003). Human leptospirosis: guidance for diagnosis, surveillance and control.

14. Widiyono. (2008). Penyakit Tropis. Epidemiologi, penularan, pencegahan dan pemberantasannya. Jakarta:
Erlangga.

15. Yunianto B. (2010). Studi epigeografi kejadian leptospirosis di Kabupaten Gresik Provinsi Jawa Timur. Laporan Akhir Penelitian. Banjarnegara: Loka Litbang P2B2 Banjarnegara; 2010. 